\title{
Proceeding
}

Supplementary Issue: Spring Conferences of Sports Science. 15th Convention and Workshop of the International Network of Sport and Health Science, 5-8 June 2019. University of Las Palmas de Gran Canaria, Las Palmas de Gran Canaria, Spain.

\section{An integrated mode to assess service volleyball among power glove, video analysis and testing}

\author{
FEDERICA FERRARA ${ }^{1}$, SIMONA FATTORE ${ }^{1}$, SALVATORE PIGNATO², TIZIANA D'ISANTO1 \\ ${ }^{1}$ University of Salerno, Italy \\ 2University Kore of Enna, Italy
}

\begin{abstract}
Technological development in recent times has had a rapid spread in various sports to have an improvement in equipment, training methods and performance of athletes through the use of tools. Although in volleyball a good use of video analysis is expected, it is not connected with other technologies. Previous studies have shown that the use of the technological tool, Power Glowe, is able to collect information on force, precision, time impact and direction of the hit when jumping and on the ground. The purpose of the study is to connect and compare the functions of video analysis with those related to the Power Glowe with the actual data on strength, speed, accuracy and tests to assess the effectiveness of the service on a sample divided in to 2 groups of female athletes, one from 12 to 16 years and the other from 18 to 26 years old with the aim of comparing the data recruited in a different way. In conclusion, we want to integrate individual methods of data recruitment to optimize the analysis and consequently the evaluation. Keywords: Test; Video analysis; Integrated evaluation; Whole assessment.
\end{abstract}

Cite this article as:

Ferrara, F., Fattore, S., Pignato, S., \& D'Isanto, T. (2019). An integrated mode to assess service volleyball among power glove, video analysis and testing. Journal of Human Sport and Exercise, 14(4proc), S739-S745. doi:https://doi.org/10.14198//hse.2019.14.Proc4.35

Corresponding author. University of Salerno, Italy.

E-mail: aciredef2212@gmail.com

Supplementary Issue: Spring Conferences of Sports Science. 15th Convention and Workshop of the International Network of Sport and Health Science, 5-8 June 2019. University of Las Palmas de Gran Canaria, Las Palmas de Gran Canaria, Spain. JOURNAL OF HUMAN SPORT \& EXERCISE ISSN 1988-5202

(c) Faculty of Education. University of Alicante

doi:10.14198/jhse.2019.14.Proc4.35 


\section{INTRODUCTION}

In sport, the spread of technologies that are able to detect and organize, in real time, a wide range of data in relation to the athlete himself, gives us a great advantage to collect information and data on performance accurately and not invasively (Di Tore, 2015, Di Tore, et al 2014).

In recent years, the changes that have occurred have led to greater use of technologies in sport (trackers, GPS, gyroscopes, accelerometers, bio-sensors built into smartphones or wearable devices) and also in volleyball (D'Isanto et al., 2019, 2018, 2017ab, Parisi, Raiola, 2014a, Raiola, 2014), leading over time to the improvement of the performance of athletes, but also of collective performance and gaming. The data acquired through the wearable technologies are processed by the computer and used by the staff to analyse both the individual athlete and the game. This allows us to also define which is the best game strategy. Volleyball is a team sport that requires great technical skills given the difference in roles in the sport. So precision is one of the basic aspects.

Among the fundamentals of volleyball there is the service, which gives rise to every action of the game (Parisi, Raiola, 2014b). The feedback method is increasingly used to acquire new skills and improve performance. Different researches have reported that objective and quantitative feedback, leads to an improvement in performance (Raiola, G., et al 2013). This study is oriented to find a correlation between anthropometric data and performance data, taking as a reference point volleyball athlete (Altavilla et al.,2017). Integrated mode to evaluate the service in volleyball between power globes, video analysis and tests. The tool collects information about players in their natural context without interfering in their behaviour also, the tool collects only data of the actions of players who can be observed (Ferrara, F., Di Tore, P.A., 2018). The objective is to investigate the difference in performance and accuracy, related to the object of investigation. The aim of data analysis is to improve knowledge of the parameters that affect performance. The design and development of a data collection tool must follow a strict protocol to ensure that the information obtained is objective, reliable, accurate and valid.

\section{METODHS}

Experimental research with physical and anthropometric tests, according to the canons of scientific study (Alminni et al, 2019, Forte et al, 2019, Raiola et al., 2018, Raiola, 2014, Raiola Di Tore, 2012abc, Raiola, 2012 , 2013). The samples are divided into two groups: group A of 12 volleyball players, $12-16$ years old, and 10 females, 18-26 years old. It chooses the tests that meet the basic parameters for simplicity, objectivity and reproducibility. The parameters to be measured and performed have been indicated for each of them. Study with physical and anthropometric tests. Choice of tests that meet the basic parameters for simplicity, objectivity and reproducibility (Forte, D., Altavilla, G. 2018). For each of them, the parameters to be measured and executed have been indicated.

\section{Anthropometric tests}

1. Height: it must be calculated placing the athlete (barefoot) with the shoulders to a wall, the heels adhering to the wall and using a team (recommended unit $0.5 \mathrm{~cm}$ );

2. Weight: the barefoot athlete climbs on a scale, possibly digital;

3. Reach with one hand: the athlete with the right flank adhering to the wall (left for left-handed people) and with adherent and parallel feet extends the arm as high as possible on the marked wall; 
4. Reach with two hands: the athlete standing perpendicular to the wall, face facing the wall, spreads his arms as high as possible on the marked wall, the measure must be calculated on the maximum height reached by the lower hand.

The following values are calculated:

- $\mathrm{BMI}$, body mass index, is the result of weight $(\mathrm{kg})$ divided by the square of height (in square $\mathrm{m})$. If the BMI is <18.5, a subject is underweight; if it is between 18.5 and 24.9 it is normal weight; if and between 25 and 29.9 it is overweight; if finally it is $>30$ it is obese.

- The ratio between reach at one hand and height (IS); ratio correlated to the schelic index ( $h$. sitting / $\mathrm{h}$. standing) this index, also influenced by other factors, indicates the degree of longevity of the subject observed.

The BMI provides an estimate of body fat and in a performance of an athletic gesture in an attitude of suspension, the BMl goes to influence the differential from the ground (Ferrara. F., Di Tore. P.A., 2018).

\section{Test of strength}

Launching a ball into a sitting position.

The test aims to measure the explosive strength of the upper limbs, which is influenced by the degree of coordination of the athlete and the length of the limbs.

Material: $1 \mathrm{~kg}$ medicine ball; chair without arms of adequate height; double decametre.

Description: The decametre is placed on the ground with the zero corresponding to the ground projection of the inside of the chair. The athlete, seated with the trunk resting on the backrest, takes the $1 \mathrm{~kg}$ medicine ball with two hands and lances it from the chest forward as far as possible without taking the shoulders off the back. Measurement: From the projection of the inside of the back to the point of arrival. Three tests are carried out in succession and the best one is recorded.

\section{Speed Test}

The test evaluates the rapidity of movement of the upper limbs.

Material: $1 \mathrm{~m}$ long wood rod.

Description: from the standing station, with the feet slightly apart, the athlete holds a wooden rod about $1 \mathrm{~m}$ long and the $\mathrm{dm}$ of $2-3 \mathrm{~cm}$, with a step equal to the width of the shoulders. The athlete pushes forward as quickly as possible, extending his arms to the maximum and always returning with the wand on his chest. Measurement: count the number of thrusts performed in 8 seconds. Perform 3 tests interspersed 3 minutes, choosing the best one.

Accuracy Test

The test evaluates the accuracy of the launch.

Material: tennis ball, mattress. 
Description: From the end of the field, throw a tennis ball down from the top with a descending trajectory, trying to hit the mat in the opponent's field at a height of 4 meters. Measurement: count the number of positive throws made in 3 tests composed of 5 shots each interspersed by 3 minutes.

Test to evaluate the effectiveness of the service based on the repetition of the technical gesture to improve performance. Model of training technique that is mainly applied for the improvement of individual actions, as the same actions are "apparently" repeated. The test consists of 2 sets of 8 bars each in the direction of a target placed in the opposing field (i.e. p1 vs p5 or p1 vs p1).

\section{RESULTS}

Table 1. Group A: Anthropometric tests

\begin{tabular}{lcc}
\hline Athlete & Height & Weight \\
\hline Sogg.1 & 1.51 & 53.2 \\
Sogg.2 & 1.59 & 47 \\
Sogg.3 & 1.59 & 61.8 \\
Sogg.4 & 1.67 & 50.9 \\
Sogg.5 & 1.57 & 52.9 \\
Sogg.7 & 1.63 & 66 \\
Sogg.10 & 1.52 & 54 \\
Sogg.11 & 1.68 & 57.4 \\
Sogg.12 & 1.53 & 58.6 \\
Sogg.13 & 1.63 & 52.7 \\
\hline
\end{tabular}

Table 2. Group B: Anthropometric tests

\begin{tabular}{lcc}
\hline Athlete & Height & Weight \\
\hline Sogg.15 & 1.58 & 56 \\
Sogg.16 & 1.58 & 57.1 \\
Sogg.17 & 1.62 & 56.1 \\
Sogg.18 & 1.70 & 66 \\
Sogg.20 & 1.62 & 56 \\
Sogg.21 & 1.58 & 47.7 \\
Sogg.22 & 1.64 & 57.4 \\
Sogg.23 & 1.60 & 59 \\
Sogg.24 & 1.75 & 56.4 \\
Sogg.25 & 1.68 & 61 \\
\hline
\end{tabular}

Table 3. Group A Statistical table

\begin{tabular}{lll}
\hline Group A $(\mathbf{n = 1 0})$ & Average & DS \\
\hline Age (year) & 13.8 & 0.6 \\
Height $(\mathrm{cm})$ & 159.3 & 5.81 \\
Weight $(\mathrm{kg})$ & 55.45 & 5.6 \\
\hline
\end{tabular}


Table 4. Group B Statistical table B

\begin{tabular}{lcc}
\hline Group B $(\mathbf{n = 1 0})$ & Average & DS \\
\hline Age $($ year) & 22.7 & 3.2 \\
Height $(\mathrm{cm})$ & 163.6 & 5.41 \\
Weight $(\mathrm{kg})$ & 57.3 & 4.6 \\
\hline
\end{tabular}

Table 5. Group A Ability test

\begin{tabular}{lcccc}
\hline \multicolumn{1}{c}{ Group A } & Strength test & Speed test & Test Accuracy & Test Service \\
\hline Sogg. 1 & 3.7 & 18 & 4 & 0 \\
Sogg. 2 & 5.3 & 24 & 5 & 1 \\
Sogg. 3 & 4.7 & 20 & 11 & 4 \\
Sogg. 4 & 4.3 & 24 & 3 & 1 \\
Sogg. 5 & 4.3 & 24 & 7 & 2 \\
Sogg. 7 & 5.75 & 22 & 7 & 3 \\
Sogg. 10 & 4.15 & 22 & 2 & 4 \\
Sogg. 11 & 5 & 22 & 6 & 0 \\
Sogg. 12 & 4.8 & 20 & 2 & 5 \\
Sogg. 13 & 4.65 & 23 & 4 & 4 \\
\hline
\end{tabular}

Table 6. Group B Ability test

\begin{tabular}{ccccc}
\hline Group B & Strength test & Speed test & Test Accuracy & Test Service \\
\hline Sogg. 15 & 5.1 & 21 & 3 & 3 \\
Sogg. 16 & 5.36 & 22 & 4 & 3 \\
Sogg. 17 & 4.84 & 23 & 1 & 3 \\
Sogg. 18 & 5.95 & 26 & 5 & 4 \\
Sogg. 20 & 4.8 & 24 & 6 & 5 \\
Sogg. 21 & 4.42 & 23 & 8 & 3 \\
Sogg. 22 & 5 & 20 & 2 & 4 \\
Sogg. 23 & 4.85 & 21 & 3 & 1 \\
Sogg. 24 & 4.5 & 22 & 2 & 0 \\
Sogg. 25 & 5.03 & 22 & 7 & 6 \\
\hline
\end{tabular}

Table 7. T-test Compared table

Difference between the two groups on the four tests performed.

\begin{tabular}{|l|c|c|c|c|}
\hline T-test & Strength test & Speed test & Test Accuracy & Test Service \\
\cline { 1 - 5 } Group A & 0.180 & 0.558 & 0.393 & 0.332 \\
\cline { 1 - 3 } Group B & 0.180 & & 0.053 \\
\hline
\end{tabular}

Significant difference with $p<0.05$.

Table 8. Group A correlation table

\begin{tabular}{|c|c|c|}
\hline \multicolumn{2}{|c|}{ Variable correlations (Gruppo A) } & \multirow[b]{2}{*}{ Low positive correlation } \\
\hline $\begin{array}{l}\text { Strength } \\
\text { Speed }\end{array}$ & 0.306 & \\
\hline $\begin{array}{l}\text { Accuracy } \\
\text { Service }\end{array}$ & -0.03 & Low negative correlation \\
\hline
\end{tabular}

Note: The negative correlation goes from -1 to 0 , while the positive correlation goes from 0 to +1 . 
Table 9. Group B correlation table

\begin{tabular}{|c|c|c|}
\hline \multicolumn{2}{|c|}{ Variable correlations (Gruppo B) } & \multirow{3}{*}{$\begin{array}{l}\text { Moderate positive correlation } \\
\text { Moderate positive correlation }\end{array}$} \\
\hline $\begin{array}{l}\text { Strength } \\
\text { Speed }\end{array}$ & 0.411 & \\
\hline $\begin{array}{l}\text { Accuracy } \\
\text { Service }\end{array}$ & 0.539 & \\
\hline
\end{tabular}

\section{CONCLUSION}

In this work, the data relating to the tests previously carried out on two groups of volleyball athletes (12-16 years) and (18-26 years) were collected, analysing their performance. These tests were carried out to understand the difference in performance and precision of the athletes by comparing these data with a technological tool, Power Glove, and video analysis. It is therefore believed that these data will confirm the hypothesis that technologies in sport can increase the level of performance and precision of athletes, and in this case, that of a fundamental detail of volleyball, the service. What should be done is to make the most of these technologies to improve the performance of athletes, and athletes could also learn the methodology and mentality of physical training more effective. This solution would improve the level of volleyball athletes and would then allow those involved in physical preparation at the highest levels to worry only about how to enhance the physical aspects (D'elia et al., 2018, Raiola, 2017).

\section{REFERENCES}

Alminni, C., Altavilla, G., Cassese, F.P., Ceciliani, A., D'isanto, T. (2019) Physical and motor tests to estimate the improvement of the float serve, Journal of Human Sport and Exercise, 14 (Proc2), pp. S245-S250. https://doi.org/10.14198/ihse.2019.14.proc2.13

Altavilla, G., Di Tore, P.A., Riela, L., D'Isanto, T. (2017) Anthropometric, physiological and performance aspects that differentiate male athletes from females and practical consequences, Journal of Physical Education and Sport, 17, art. no. 226, pp. 2183-2187.

D'Elia, F., Mazzeo, F., \& Raiola, G. (2018). The core curriculum in the university training of the teacher of physical education in Italy. Journal of Human Sport and Exercise, 13(2proc), S413-S420. https://doi.org/10.14198/ihse.2018.13.Proc2.25

D'Isanto, T., D'Elia, F., Raiola, G., Altavilla, G. (2019) Assessment of sport performance: Theoretical aspects and practical indications, Sport Mont, 17 (1), pp. 79-82.

D'Isanto, T., Di Tore, P.A., Altavilla, G. (2018) Correlation of the anthropometric characteristics and the ability to jump in volleyball, Journal of Human Sport and Exercise, 13, pp. S393-\$400. https://doi.org/10.14198/ihse.2018.13.proc2.23

D'Isanto, T., Altavilla, G., Raiola, G. (2017a) Teaching method in volleyball service: Intensive and extensive tools in cognitive and ecological approach, Journal of Physical Education and Sport, 17, art. no. 233, pp. 2222-2227.

Di Tore, P.A. (2015) Situation awareness and complexity: The role of wearable technologies in sports science, Journal of Human Sport and Exercise, 10 (Specialissue1), pp. S500-S506. https://doi.org/10.14198//hse.2015.10.proc1.44

Di Tore, S., Aiello, P., Di Tore, P.A., Sibilio, M. (2014) The extended body in the teaching-learning process, Educational Technology Use and Design for Improved Learning Opportunities, pp. 261268. https://doi.org/10.4018/978-1-4666-6102-8.ch014 
Ferrara. F., Di Tore. P.A, (2018) Preliminary work on the testing of Power Glove applied to volleyball, Journal of Physical Education and Sport, 18.

Ferrara, F., Izzo, R., Ceciliani, A., \& Di Tore, A.P. (2019). Pilot study on the testing of Power Glove applied to volleyball. Journal of Human Sport and Exercise, 14(2proc), S233-S238. https://doi.org/10.14198/ihse.2019.14.Proc2.11

Forte, D., Ceciliani, A., Izzo, R., Altavilla, G. (2019) Transition period: Pilot study on performance reduction of ability to jump in volleyball, Journal of Human Sport and Exercise, 14 (Proc2), pp. S221S227. https://doi.org/10.14198/ihse.2019.14.proc2.09

Forte, D., Altavilla, G. (2018) Preliminary correlation between anthropometric and performance data in volleyball about the transition period Journal of Physical Education and Sport, 18, 1994-1998.

Parisi, F., Raiola, G. (2014a) The serve in under 12-13 Italian volleyball team, Journal of Human Sport and Exercise, 9, pp. S588-S591. https://doi.org/10.14198/jhse.2014.9.proc1.51

Parisi, F., Raiola, G. (2014b) Video analysis in youth volleyball team, Journal of Human Sport and Exercise, 9, pp. S584-S587. https://doi.org/10.14198/ihse.2014.9.proc1.50

Raiola, G., D'elia, F., Altavilla, G. (2018) Physical activity and sports sciences between European Research Council and academic disciplines in Italy, Journal of Human Sport and Exercise, 13, pp. S283-S295. https://doi.org/10.14198/jhse.2018.13.proc2.13

Raiola, G. (2014) Teaching method in young female team of volleyball, Journal of Physical Education and Sport, 14 (1), pp. 74-78.

Raiola, G. (2013) Body knowledge and motor skills Knowledge Cultures, 1 (6), pp. 64-72.

Raiola, G. (2012) Bodily communication in volleyball between human and experimental sciences, Mediterranean Journal of Social Sciences, 3 (1), 587-597.

Raiola, G., Di Tore, A. (2012a) Non-verbal communication and volleyball: A new way to approach the phenomenon. Mediterranean Journal of Social Sciences, 3 (2), pp. 347-356. https://doi.org/10.5901/miss.2012.v3n2.347

Raiola, G., Di Tore, P.A. (2012b) Statistical study on bodily communication skills in volleyball to improve teaching methods, Journal of Human Sport and Exercise, 7 (2), pp. 468-488. https://doi.org/10.4100/jhse.2012.72.12

Raiola, G., Di Tore, P.A. (2012c) Bodily communication skills and its incidence on female volleyball championship to enhance didactics, Journal of Human Sport and Exercise, 7 (2), pp. 365-375. https://doi.org/10.4100/ihse.2012.72.03

Raiola, G., Parisi, F., Giugno, Y., Di Tore, P.A. (2013) Video analysis applied to volleyball didactics to improve sport skills, Journal of Human Sport and Exercise, 8 307-313. https://doi.org/10.4100/jhse.2012.8.proc2.33

Raiola, G., D'elia, F., Altavilla, G. (2018) Physical activity and sports sciences between European Research Council and academic disciplines in Italy Journal of Human Sport and Exercise, 13, pp. S283-S295. https://doi.org/10.14198/jhse.2018.13.proc2.13

\section{(9) $(\mathbb{Q} \Theta \Theta$}

This work is licensed under a Attribution-NonCommercial-NoDerivatives 4.0 International (CC BY-NC-ND 4.0). 